\title{
Comparative study between patients with acute appendicitis treated in primary care units and in emergency hospitals
}

\section{Comparativo entre pacientes com diagnóstico de apendicite aguda atendidos em unidades de pronto atendimento e hospital de emergência}

\author{
Thiago de Paula Bon'; Patrícia Frascari1; Marcos de Assis Moura²; Marcus Vinicius Dantas de Campos Martins, TCBC-RJ'.
}

A B S T R A C T

\begin{abstract}
Objective: To retrospectively analyze the relationship of time of care, combined with possible post-appendectomy complications, with the promptness of transfer of patients seen in Emergency Care Units (UPA) to the emergency hospital. Methods: We analyzed patients with preoperative diagnosis of acute appendicitis undergoing appendectomy from January to July 2012. Patients were divided into two groups according to the site of the first care. Group A included patients who received initial care directly in the emergency department of the Lourenço Jorge County Hospital (HMLJ) and group B consisted of patients seen in the UPA and forwarded to $\mathrm{HMLJ}$ to undergo surgical treatment. Results: the average time between initial treatment and surgery in group $A$ was 29 hours $(S D=21.95)$ and 54 hours in group B $(S D=54.5)$. Considering the onset of symptoms, the patients in group $A$ were operated on average 67 hours after (SD $=42.55)$, while group $B, 90$ hours $(S D=59.58$ ). After the operation, patients in group $A$ were hospitalized, on average, for 94 hours $(S D=73.53)$ and group $B, 129$ hours $(S D=193.42)$. Conclusion: there was no significant difference in the time elapsed between the onset of symptoms, initial treatment and early surgical treatment, or time elapsed between surgery and discharge.
\end{abstract}

Key words: Appendicitis. Length of stay. Appendectomy. Postoperative complications.

\section{INTRODUCTION}

A cute appendicitis is the most common cause of emergency care in hospitals and it is the most frequent abdominal inflammatory disease of surgical treatment in young people ${ }^{1,2}$. It predominates in males at a ratio of 1.4 : 1 and the lifelong risk of developing it is $8.6 \%$ for men and $6.7 \%$ for women ${ }^{3}$.

Abdominal pain is the most common and early symptom. It starts in the mesogastric region and migrates to the right iliac fossa ${ }^{4}$, having a strong association with the diagnosis of acute appendicitis ${ }^{5}$.

In recent years, ultrasound (US) and computed tomography (CT) have been widely used in patients with a clinical features of acute appendicitis to clarify the diagnosis ${ }^{6}$. The ultrasound has a sensitivity of $85 \%^{7}$. However, CT has higher accuracy ${ }^{8}$. The use of this exam in patients with suspected appendicitis or in those with diagnostic uncertainty greatly decreased the rates of negative laparotomy ${ }^{9}$.

Disease severity is directly connected to evolution time. Perforation is the most common complication and is associated with delayed diagnosis. Thirty-six hours after the onset of symptoms the risk of perforation is $16-36 \%$, and this risk increases approximately $5 \%$ every 12 hours ${ }^{10}$.
Morbidity and mortality are also related to the time evolution and hence to perforation. The mortality rate in nonperforated appendicitis is $0.08 \%$ and $0.51 \%$ in the cases where there is perforation ${ }^{11}$. Similarly, the complications are more frequent in patients operated later ${ }^{1}$. Thus, efforts must be focused on early diagnosis and treatment, aiming at lower morbidity and mortality.

In 2003, the Brazilian Ministry of Health established a National Policy for Emergency Department in order to structure and organize the network of emergency care in the country ${ }^{12}$. The Emergency Care Units (UPAs) are structures of intermediate complexity that are part this program. After risk classification, patients with abdominal pain and clinical suspicion of acute appendicitis seen in these units may, according to a regulation system, be referred to an emergency hospital for surgical treatment.

Since the morbidity and mortality of acute appendicitis are directly linked to the progression of the disease, a delay in treatment due to the need for a transfer between healthcare facilities could increase complications and mortality in this group of patients. Therefore, we decided to retrospectively analyze relationship of time of care, combined with possible post-appendectomy complications,

1 Lourenço Jorge County Hospital, Rio de Janeiro, Brazil; 2 Faculty of Medicine, Gama Filho University, Rio de Janeiro, Brazil. 
with the promptness of transfer of patients seen in the UPAs to the emergency hospital.

\section{METHODS}

We retrospectively analyzed the patients who underwent appendectomy at the LorenzoCounty Hospital (HMLJ) in Rio de Janeiro between the months of January and July of 2012. Patients were divided into two groups according to the place where they received the first care. Group A consisted of patients who spontaneously sought the emergency room of HMLJ, where they were operated. Group B consisted of patients initially treated at UPAs of Rio de Janeiro, and later taken to the HMLJ for surgical treatment after effective evaluation of signs and symptoms and diagnostic confirmation. Elapsed times evaluated were: between onset of symptoms and start of appendectomy (t1); between the initial treatment and start of appendectomy (t2); and between the operation and hospital discharge (t3). The time intervals were measured in hours. We analyzed and compared the complications in each group. The Student $t$ test was used for evaluation of time intervals and we considered $p$ values $<0.05$ as statistically significant.

\section{RESULTS}

We analyzed medical records of 24 patients in group A and 34 in group B. The males prevailed in both groups and there was no difference in mean age between groups (Table 1).

All patients had abdominal pain. There was no significant difference between the number of patients who had localized or diffuse pain between the groups. However, we found a high percentage of patients with diffuse abdominal pain. Sixty-eight percent of patients in group B had vomiting (Figure 1).

Intraoperative evaluation demonstrated that $63 \%$ of patients in group A and $66 \%$ of group B had suppurating appendicitis with perforation or necrosis (Table 2).

There was no significant difference in the time interval between symptom onset and appendectomy (t1,) between the initial treatment and appendectomy (t2) and the time of hospitalization after surgery (t3), although the average time in hours was higher in group B (Table $3)$.

The percentage of complications was similar, regardless of the location of the initial treatment (Table 4).

\section{DISCUSSION}

The Emergency Care Units, part of the National Emergency Policy, allowed more health facilities to be available to the population and closer to their homes. On the other hand, the inclusion of a further step in the treatment of those whose prognoses are connected to early treatment could worsen results and increase morbidity and mortality.

It its known that even in developed countries like the United States, patients undergoing appendectomy for acute appendicitis at government hospitals more often present with perforation and require longer hospital stay compared with those treated in private hospitals ${ }^{13}$. According to data from the US National Hospital Ambulatory Medical Care Survey, between 1997 and 2006 the waiting time for diagnosis was higher in the lower income population ${ }^{14}$. The same happens in our country. Coelho et al. published longer hospital stays, greater number of postoperative complications and delayed return to normal activities in

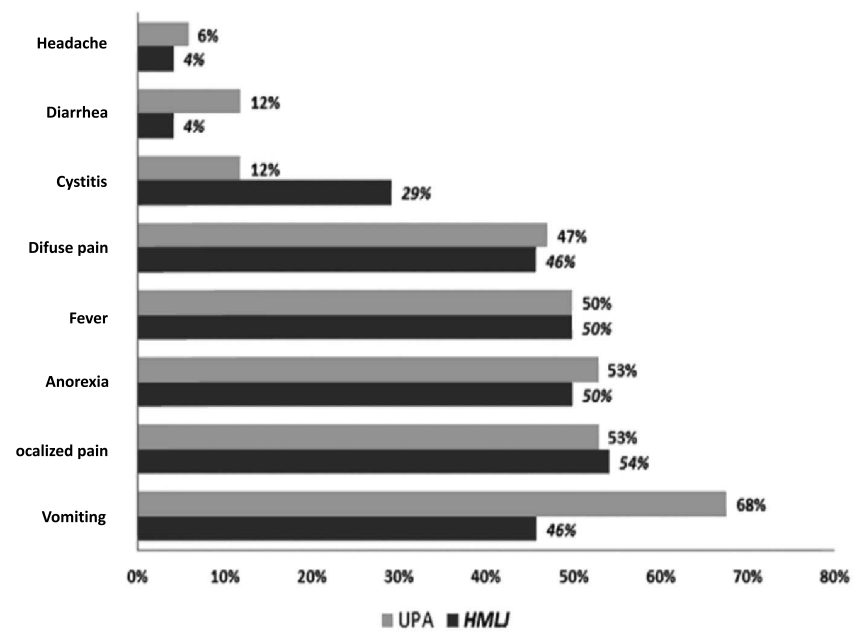

Figure 1 - Comparison of percentage of signs and symptoms observed in patients seen in the UPA and in HMLJ.

Table 1 - Patients undergoing appendectomy, according to gender and average age.

\begin{tabular}{lrrrr}
\hline & \multicolumn{2}{c}{ Group A } & \multicolumn{2}{c}{ Group B } \\
\hline Cases & 24 & 34 & & \\
Men & 17 & $(71 \%)$ & 23 & $(68 \%)$ \\
Women & 7 & $(29 \%)$ & 11 & $(32 \%)$ \\
Average age & $24.63 \pm$ & 16.67 & $27.75 \pm 13.91$ \\
\hline
\end{tabular}


Table 2 - Intraoperative Findings.

\begin{tabular}{lrrrr}
\hline Found Intraoperatively & \multicolumn{2}{c}{ Group A } & Group B \\
\hline Negative & 1 & $(4 \%)$ & 3 & $(9 \%)$ \\
Phase 1- Inflammatory & 8 & $(33 \%)$ & 12 & $(35 \%)$ \\
Phase 2- Suppurated/Perforated & 10 & $(42 \%)$ & 15 & $(44 \%)$ \\
Phase 3- Necrosis & 5 & $(21 \%)$ & 4 & $(12 \%)$ \\
\hline
\end{tabular}

Table 3 - Average time, in hours, between the first care until hospital discharge, according to the location of the first care.

\begin{tabular}{llrr}
\hline & Group A & Group B & P \\
\hline t1 & $67 \pm 42.55$ hours & $90 \pm 59.58$ hours & 0.18 \\
t2 & $29 \pm 21.95$ hours & $54 \pm 54.5$ hours & 0.34 \\
t3 & $94 \pm 73.53$ hours & $129 \pm 193$ hours & 0.66 \\
\hline
\end{tabular}

Table 4 - $\quad$ Percentage of complications observed after appendectomy by according to the location of the first care.

\begin{tabular}{|c|c|c|}
\hline Complications & Group A & Group B \\
\hline Intra-abdominal abscess & $1 \quad(4)$ & (3) \\
\hline Dehiscence of anastomosis & $1 \quad(4)$ & (3) \\
\hline Diarrhea & $0 \quad(0)$ & (0) \\
\hline Abdominal Pain & $1 \quad(4)$ & (0) \\
\hline Evisceration & $1 \quad(4)$ & (0) \\
\hline Fever & $0 \quad(0)$ & (3) \\
\hline Surgical wound infection & $1 \quad(4)$ & (3) \\
\hline Intestinal obstruction & $0 \quad(0)$ & (3) \\
\hline Septicemia & $1 \quad(4)$ & (0) \\
\hline Vomiting & $3(13)$ & $5 \quad(15)$ \\
\hline Death & $1 \quad(4)$ & $1 \quad(3)$ \\
\hline
\end{tabular}

patients operated in a public hospital when compared with those operated on a private unit ${ }^{15}$.

In this study, it appears that, regardless of the location of the first visit, the patients clearly showed a long time between onset of symptoms and surgical treatment, as well as a prolonged mean hospital stay, even compared with other Brazilian public hospitals ${ }^{16}$.

Also noteworthy is the high number of appendicitis with perforation and necrosis, compatible with advanced disease and therefore with a worse prognosis.
One can also observe a trend of increase of the time elapsed between onset of symptoms and surgery (t1), of the time between the initial treatment and surgery (t2), as well as increased length of postoperative hospital stay (t3 ) in patients initially treated at UPAs when compared with those treated directly at the Hospital. However, as for the quantum analyzed, this difference was not significant. An amplification of the number of patients could confirm this finding. 


\section{R E S U M O}

Objetivo: analisar, retrospectivamente, a relação tempo de atendimento aliado a possíveis complicações pós-apendicectomia com a presteza de transferência de pacientes atendidos em Unidades de Pronto Atendimento (UPA) para hospital de emergência. Métodos: foram analisados, no período de janeiro a julho de 2012, pacientes com diagnóstico pré-operatório de apendicite aguda, submetidos à apendicectomia. Os pacientes foram distribuídos em dois grupos conforme o local do primeiro atendimento. O grupo A incluiu os pacientes que receberam primeiro atendimento diretamente no setor de emergência do Hospital Municipal Lourenço Jorge (HMLJ) e o grupo B, constituiu-se de pacientes atendidos nas UPA e encaminhados para o HMLJ a fim de serem submetidos ao tratamento cirúrgico. Resultado: o tempo médio decorrido entre o atendimento inicial e a cirurgia, no grupo $A$, foi 29 horas $(D P=21,95)$ e de 54 horas no grupo $B(D P=54,5)$. Considerando o início dos sintomas, os pacientes do grupo $A$ demoraram, em média, 67 horas para serem operados $(D P=42,55)$, enquanto os do grupo $B, 90$ horas $(D P=59,58)$. Após a operação, os pacientes do grupo A ficaram internados, em média, 94 horas $(D P=73,53)$ e os do grupo $B, 129$ horas $(D P=193,42)$. Conclusão: após análise dos resultados, concluiu-se que não houve diferença significativa no tempo decorrido entre o início dos sintomas, o atendimento inicial e o início do tratamento cirúrgico, nem no tempo decorrido entre o tratamento cirúrgico e a alta hospitalar.

Descritores: Apendicite. Tempo de internação. Apendicectomia. Complicações pós-operatórias.

\section{REFERENCES}

1. Nutels DBA, Andrade ACG, Rocha AC. Perfil das complicações após apendicectomia em um hospital de emergência. $A B C D$, arq bras cir dig. 2007;20(3):146-9.

2. van Randen A, Laméris W, van Es HW, ten Hove W, Bouma WH, van Leeuwen MS, et al. Profiles of US and CT imaging features with a high probability of appendicitis. Eur Radiol. 2010;20(7):165766.

3. Addiss DG, Shaffer N, Fowler BS, Tauxe RV. The epidemiology of appendicitis and appendectomy in the United States. Am J Epidemiol. 1990;132(5):910-25.

4. Humes DJ, Simpson J. Acute Appendicitis. BMJ. 2006;333(7567):530-4.

5. Andersson R. Meta-analysis of the clinical and laboratory diagnosis of appendicitis. Br J Surg. 2004;91(1):28-37.

6. van Randen A, Bipat $S$, Zwinderman AH, Ubbink DT, Stoker J, Boermeester MA. Acute appendicitis: meta-analysis of diagnostic performance of CT and graded compression US related to prevalence of disease. Radiology. 2008;249(1):97-106.

7. Torres OJM, Lins AAL, Nunes PMS, Corrêa FCF, Carvalho Júnior OS, Castro FC. Avaliação ultra-sonográfica da apendicite aguda. Rev Col Bras Cir. 2001;28(1):39-43.

8. Weston AR, Jackson TJ, Blamey S. Diagnosis of appendicitis in adults by ultrasonography or computed tomography: a systematic review and meta-analysis. Int J Technol Assess Health Care. 2005; 21(3):368-79.

9. Rosengren D, Brown AF, Chu K. Radiological imaging to improve the emergency department diagnosis of acute appendicitis. Emerg Med Australas. 2004;16(5-6):410-6.
10. Bickell NA, Aufses AH Jr, Rojas M, Bodian C. How time affects the risk of rupture in appendicitis. J Am Coll Surg. 2006;202(3):401-6.

11. Blomqvist PG, Andersson RE, Granath F, Lambe MP, Ekbom AR. Mortality after appendectomy in Sweden, 1987-1996. Am Surg. 2001;233(4):455-60.

12. Brasil. Ministério da Saúde. Política nacional de atenção às urgências / Ministério da Saúde. $3^{a}$ ed ampl. Brasília: Ministério da Saúde; 2006

13. Lee SL, Yaghoubian A, Kaji A. County versus private hospitals: access of care, management and outcomes for patients with appendicitis. JSLS. 2012;16(2):283-6.

14. Wu BU, Banks PA, Conwell DL. Disparities in emergency department wait times for acute gastrointestinal illnesses: results from the National Hospital Ambulatory Medical Care Survey, 1997-2006. Am J Gastroenterol. 2009; 104(7):1668-73.

15. Coelho JC, Fernandes FM, Cortiano LG, Leme GM, Sadowski JA, Artner CL. Appendectomy. Comparative study between a public and a private hospital. Rev Assoc Med Bras. 2010;56(5):522-7.

16. Franzon O, Piccoli MC, Neves TT, Volpato MG. Apendicite aguda: análise institucional no manejo peri-operatório. $A B C D$, arq bras cir dig. 2009;22(2):72-5.

Received on 05/12/2013

Accepted for publication 25/01/2014

Conflict of interest: none.

Source of funding: none.

Mailing address:

Marcus Vinicius Dantas de Campos Martins

E-mail: mvdantas@hotmail.com 